\title{
LC DETERMINATION OF ROSUVASTATIN AND EZETIMIBE IN HUMAN PLASMA
}

\author{
${ }^{a}$ MUHAMMAD ASHFAQ*, ${ }^{b} H A M A D$ AHMAD, ${ }^{b} I S L A M$ ULLAH KHAN, AND ${ }^{a}$ GHULAM MUSTAFA \\ ${ }^{a}$ Department of Chemistry, University of Gujrat, H. H. Campus Gujrat-50700, Pakistan \\ ${ }^{b}$ Materials Chemistry Laboratory, Department of Chemistry, Faculty of Science and Technology, Government College University, Lahore-54000, Pakistan
}

(Received: May 31, 2013 - Accepted: September 5, 2013)

\begin{abstract}
A simple, precise, sensitive and validated reverse-phase high performance liquid chromatographic (RP-HPLC) method was developed for the simultaneous estimation of rosuvastatin and ezetimibe in human plasma. The method involved protein precipitation and extraction of both drugs from plasma using acetonitrile and then separation on a C-18 column. Both the analytes were detected at a wavelength of $240 \mathrm{~nm}$ using diode array detector. Mobile phase for the said separation consists of a mixture of $1.5 \%$ phosphoric acid and acetonitrile in 30:70, v/v ratio. Linearity was in the range of $0.32-267 \mathrm{mg} / \mathrm{mL}$ for rosuvastatin and $0.08-67$ $\mathrm{mg} / \mathrm{mL}$ for ezetimibe with coefficient of determination between 0.9997 and 0.9967 . Limit of detection was $0.106 \mu \mathrm{g} / \mathrm{mL}$ for rosuvastatin and $0.026 \mathrm{mg} / \mathrm{mL}$ for ezetimibe whereas limit of quantification was $0.32 \mathrm{mg} / \mathrm{mL}$ and $0.08 \mathrm{mg} / \mathrm{mL}$ for rosuvastatin and ezetimibe respectively. Recovery of both the analytes was greater than $75 \%$ with RSD less than $15 \%$. The total run time was less than five min for the two components. The developed method can be fruitfully employed for the determination of these two drugs in human plasma.
\end{abstract}

Key words: HPLC, Acetonitrile, Diode Array Detector, Rosuvastatin, Ezetimibe

\section{1-INTRODUCTION}

Rosuvastatin Figure (1) is the calcium salt of (E)-7-[4-(4-fluorophenyl)6-isopropyl-2- [methyl(methylsulfonyl)amino]pyrimidi n-5-yl](3R,5S)-3,5dihydroxyhept-6- enoic acid and a competitive inhibitor of HMG-CoA reductase [1-2]. It is used in the treatment of hypercholesterolemia and dyslipidemia [3-4]. Rosuvastatin is very effective in reducing low density lipoprotein cholesterol [5] and many studies have demonstrated its efficacy greater than other drugs of its class such as atorvastatin, simvastatin and pravastatin [57]. During literature review many methods were found reporting separation of rosuvastatin like capillary zone electrophoresis [8], Spectrophotometry [9-10] and HPLC [11-14].<smiles>CC(C)c1nc(N(C)S(C)(=O)=O)nc(-c2ccc(F)cc2)c1/C=C\C(=O)[O-]</smiles>

Figure 1: Chemical structure of rosuvastatin calcium.

Ezetimibe (Figure 2), designated as 1-(4-fluorophenyl)-3(R)-[3-(4fluorophenyl)-3(S)-hydroxypropyl]- 4(S)-(4-hydroxyphenyl)-2-azetidinone is a selective inhibitor of intestinal cholesterol and related phytosterol absorption. It stops cholesterol transport through the intestinal wall by selectively blocking the absorption of cholesterol from dietary and billiary sources [15-16]. It does not appear to compromise the absorption of fat-soluble vitamins, triglycerides and bile acids [17-19]. Many analytical methods are reported in the literature for ezetimibe using different techniques [20-29].

Literature survey also revealed some analytical methods for the simultaneous determination of rosuvastatin and ezetimibe. These include spectrophotometry [30-31], HPTLC [32], Micellar liquid chromatography [33] and simultaneous equation method [34]. Recently Varghese et al [35] reported an RP-HPLC method for the simultaneous determination of rosuvastatin and ezetimibe. The method has some limitations as its linear range were narrow and have high detection limits of $0.5 \mu \mathrm{g} / \mathrm{mL}$ for both drugs. Secondly the method was applied for the determination of both the drugs in pharmaceutical formulations.

We are currently engaged in the development of simple HPLC methods for the determination of binary combinations of different classes of drugs including antihyperlipidemic drugs $[21,22,36-46]$. The present work was therefore planned to develop a simple HPLC method to determine rosuvastatin and ezetimibe simultaneously in human plasma. During this study, a simple, economic and sensitive HPLC method with run time less than five min was developed in human plasma. The developed method have superiority over the Varghese et al method in that its linear range is $0.32-267 \mu \mathrm{g} / \mathrm{mL}$ for rosuvastatin and $0.08-67 \mu \mathrm{g} / \mathrm{mL}$ for ezetimibe and also the method is applied for human plasma. The method could have the potential to be used for any sort of studies planned for conducting in human plasma.

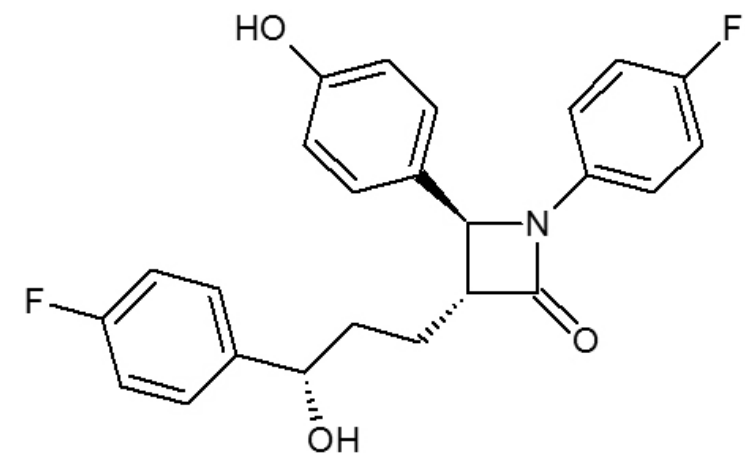

Figure 2: Chemical Structure of Ezetimibe

\section{2-EXPERIMENTAL}

\subsection{Chemicals and Reagents}

Pure raw materials of rosuvastatin calcium and ezetimibe to be used as references materials were kindly provided by Schazzo Zaka Laboratories Lahore, Pakistan, with claimed purity of 99.63 and $99.74 \%$ respectively. Acetonitrile (HPLC grade) and Phosphoric acid (Analytical grade), both of Fluka origin were purchased from the local market. Double distilled water was prepared in our laboratory using glass distillation apparatus.

2.2. Apparatus and chromatographic conditions

A Shimadzu LC-20A system comprising a model LC-20AT pump, an SPDM20A diode array detector, a CBM-20A interface module with class LC-20 HPLC software, and a Rheodyne injection valve with a $20 \mu \mathrm{L}$ loop was used for development and evaluation of the method. Compounds were separated on a $250 \mathrm{~mm} \times 4.6 \mathrm{~mm}$ i.d., $5-\mu \mathrm{m}$ particle, Merck C18 column. Mobile phase for the 
said separation was prepared by mixing $1.5 \%$ phosphoric acid and acetonitrile in 30:70, v/v ratio and it was run at a flow rate of $1 \mathrm{~mL} / \mathrm{min}$. Before use, mobile phase was filtered through $0.45 \mu \mathrm{m}$ nylon filters from Millipore (USA) and was degassed by sonication. Both the analytes were detected at $240 \mathrm{~nm}$ and at room temperature. Peak identity was confirmed by comparison of spectra and retention times with those of standards.

2.3 Preparation of standard solutions

The standard stock solution was prepared by dissolving $40 \mathrm{mg}$ rosuvastatin and $10 \mathrm{mg}$ ezetimibe to a small amount of mobile phase in a $50 \mathrm{~mL}$ volumetric flask and then raising the volume up to the mark with mobile phase. The final concentration thus attained was $800 \mu \mathrm{g} / \mathrm{mL}$ and $200 \mu \mathrm{g} / \mathrm{mL}$ for rosuvastatin and ezetimibe respectively.

2.4 Preparation of working solution

A volume equal to $1 \mathrm{~mL}$ of the standard solution was taken in $25 \mathrm{~mL}$ measuring flask and its volume was raised till mark with mobile phase.

2.5 Linearity

Linearity of the proposed method was evaluated by analyzing seven solutions in the range of $0.08-67 \mu \mathrm{g} / \mathrm{mL}(0.08 \mu \mathrm{g} / \mathrm{mL}, 0.8 \mu \mathrm{g} / \mathrm{mL}, 2.0 \mu \mathrm{g} / \mathrm{mL}$, $5.0 \mu \mathrm{g} / \mathrm{mL}, 22.0 \mu \mathrm{g} / \mathrm{mL}, 40.0 \mu \mathrm{g} / \mathrm{mL}, 67 \mu \mathrm{g} / \mathrm{mL}$ ) for ezetimibe and $0.32-267$ $\mu \mathrm{g} / \mathrm{mL}(0.32 \mu \mathrm{g} / \mathrm{mL}, 3.2 \mu \mathrm{g} / \mathrm{mL}, 8 \mu \mathrm{g} / \mathrm{mL}, 20 \mu \mathrm{g} / \mathrm{mL}, 89 \mu \mathrm{g} / \mathrm{mL}, 160 \mu \mathrm{g} / \mathrm{mL}$, $267 \mu \mathrm{g} / \mathrm{mL}$ ) for rosuvastatin. All these concentrations were prepared in human plasma by mixing appropriate quantity of working solution with $1 \mathrm{~mL}$ of human plasma. This mixture was then vortexed manually for about 30 seconds before adding $3 \mathrm{~mL}$ of acetonitrile in each concentration. After the acetonitrile addition the solution was mixed for about $3 \mathrm{~min}$. The solutions were then centrifuged for 10 min at 3500 RPM to precipitate the plasma protein. Half of the supernatant out of the total volume of solution was then taken in a glass vial and evaporate at $40^{\circ} \mathrm{C}$ in incubator. To the dry residue of each vial, $2 \mathrm{~mL}$ of mobile phase was added, mixed to dissolve the contents and analyzed immediately after filtration.

\subsection{Extraction Recovery}

In order to check recovery of rosuvastatin and ezetimibe from spiked human plasma, four concentrations were considered from the linearity range. The results of these concentrations were then compared with the results of same concentrations but without human plasma. Each concentration was analyzed in triplicates and their results were calculated in terms of \% recovery.

\subsection{Precision}

The Intra-day and inter-day precision was performed for the same four concentrations of samples as used for extraction recovery. For intra-day precision samples were analyzed in triplicates within the same day and for inter-day precision they were analyzed for consecutive three days and precision was expressed in terms of $\%$ RSD.

\subsection{Limit of detection and quantitation}

A limit of detection is the lowest concentration at which the analytes could be detected. It is usually measured when the signal to noise ratio is 3:1. Limit of quantitation is the lowest concentration of the analytes which can be quantified with accuracy and precision. It is measured when the signal to noise ratio is 10:1. These limits were determined by analyzing the blank solution and the solutions with known progressively decreasing concentrations of analytes.

\section{3- RESULTS AND DISCUSSION}

In this work a simple, accurate and sensitive HPLC method for the simultaneous determination of rosuvastatin and ezetimibe in their fixed binary combination is developed and validated. Both rosuvastatin and ezetimibe are not found yet in any pharmacopeia in combined dosage form. Therefore the aim behind this work was to develop a simple, isocratic, and sensitive HPLC method for the simultaneous determination of rosuvastatin and ezetimibe in human plasma. Method development was started with $0.1 \mathrm{M}$ ammonium acetate buffer $\mathrm{pH} 5.0$ and acetonitrile in various ratios with Merck C-18 column but in the entire conditions peak tailing of rosuvastatin was greater than 1.5 and also the peak shape was not good. The column was then replaced with new Hypersil C-18 column, Discovery Monolithic Column and Phenyl Column but peak shape and tailing of rosuvastatin was not improved. The mobile phase was then switched from ammonium acetate to phosphoric acid solution. Phosphoric acid solution along with acetonitrile was good enough to separate both the analytes with good peak shape with tailing less than 1.5. The chromatographic conditions were then optimized to get good resolution between the two analytes. The best results were obtained using mobile phase of $1.5 \%$ phosphoric acid and acetonitrile in the ratio of $(30: 70, \mathrm{v} / \mathrm{v})$ on a Merck C-18 column. So by applying the optimum chromatographic conditions, resolved sharp peaks that belong to rosuvastatin and ezetimibe were obtained within $7 \mathrm{~min}$. The represented chromatograms of ezetimibe and rosuvastatin are given in Figure 3.

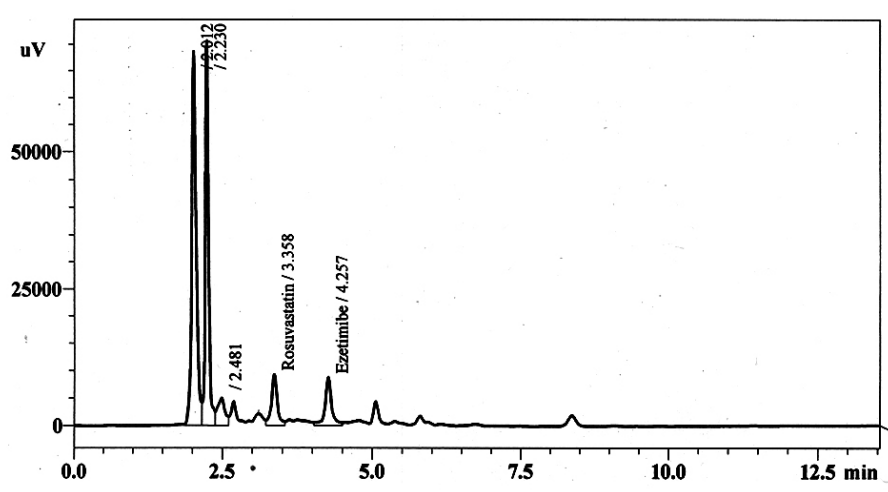

Figure 3: Chromatogram showing rosuvastatin and ezetimibe in blood plasma at LOQ level

The developed chromatographic method was validated in accordance with ICH guidelines.

The Linearity of the method was measured by analyzing seven solutions in the range of $0.08-67 \mu \mathrm{g} / \mathrm{mL}(0.08 \mu \mathrm{g} / \mathrm{mL}, 0.8 \mu \mathrm{g} / \mathrm{mL}, 2.0 \mu \mathrm{g} / \mathrm{mL}, 5.0 \mu \mathrm{g} /$ $\mathrm{mL}, 22.0 \mu \mathrm{g} / \mathrm{mL}, 40.0 \mu \mathrm{g} / \mathrm{mL}, 67 \mu \mathrm{g} / \mathrm{mL}$ ) for ezetimibe and $0.32-267 \mu \mathrm{g} / \mathrm{mL}$ $(0.32 \mu \mathrm{g} / \mathrm{mL}, 3.2 \mu \mathrm{g} / \mathrm{mL}, 8 \mu \mathrm{g} / \mathrm{mL}, 20 \mu \mathrm{g} / \mathrm{mL}, 89 \mu \mathrm{g} / \mathrm{mL}, 160 \mu \mathrm{g} / \mathrm{mL}, 267 \mu \mathrm{g} /$ $\mathrm{mL}$ ) for rosuvastatin. Each concentration was made and analyzed in triplicate. The peak areas obtained against each concentration of the analytes were used to build a linear regression equation and to determine value of coefficient of determination. Good linearity was observed over the above mentioned range with linear regression equation $\mathrm{Y}=79787 \mathrm{X}+65485$ for ezetimibe and $\mathrm{Y}=$ $89725 \mathrm{X}-41670$ for rosuvastatin. The value of coefficient of determination was found to be 0.9967 for ezetimibe and 0.9997 for rosuvastatin. The linearity graphs for ezetimibe and rosuvastatin are shown in Figure 4 and Figure 5.

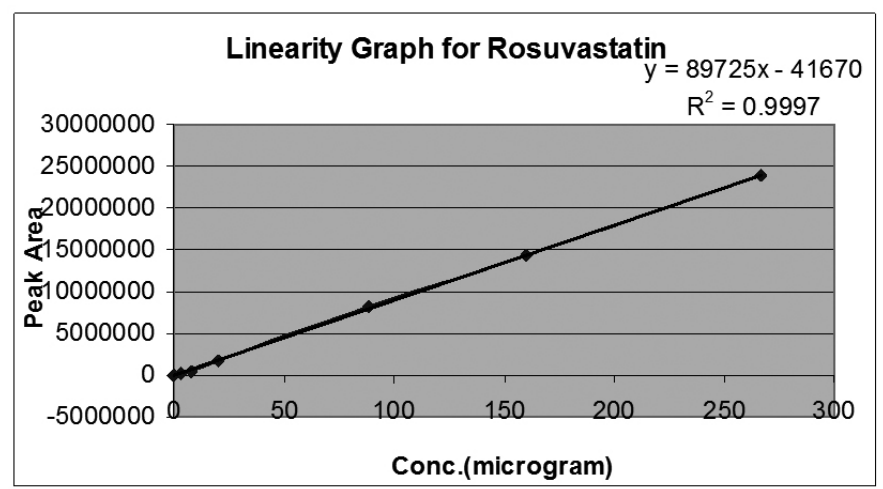

Figure: 4 Linearity graph of Rosuvastatin

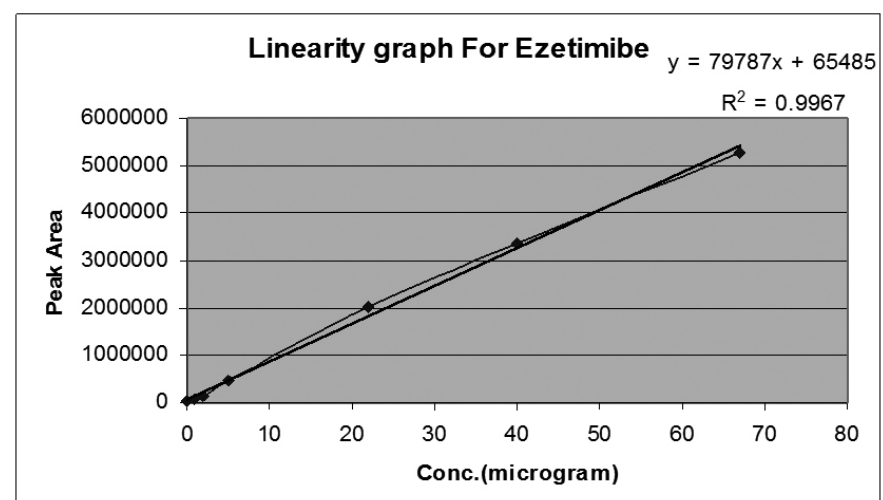

Figure 5: Linearity graph of Ezetimibe

To calculate the limit of detection (LOD) and limit of quantification (LOQ), a blank solution and a solution spiked with known progressively decreasing 
concentrations of each analyte were prepared and analyzed by the developed method. The LOD values were found to be $0.026 \mu \mathrm{g} / \mathrm{mL}$ for ezetimibe and $0.106 \mu \mathrm{g} / \mathrm{mL}$ for rosuvastatin. The LOQ values were $0.08 \mu \mathrm{g} / \mathrm{mL}$ and $0.32 \mu \mathrm{g} /$ $\mathrm{mL}$ for ezetimibe and rosuvastatin, respectively.

Extraction recovery for ezetimibe and rosuvastatin was checked by considering four concentrations from the linearity range. These concentrations were made in plasma and without plasma and then analyzed in triplicates. Results were compared and recovery was calculated in terms of percentage recovery. Recovery of ezetimibe and rosuvastatin were found to be greater than $87 \%$ as shown in Table 1.

Table 1. Extraction Recovery of the proposed HPLC method

\begin{tabular}{|llllll|}
\hline Compound & $\mathrm{n}$ & $\begin{array}{c}\text { Actual Conc. } \\
(\mu \mathrm{g} / \mathrm{mL})\end{array}$ & $\begin{array}{c}\text { Measured Conc. } \\
(\mu \mathrm{g} / \mathrm{mL})\end{array}$ & $\begin{array}{c}\text { Recovery } \\
(\%)\end{array}$ & $\begin{array}{r}\text { RSD } \\
(\%)\end{array}$ \\
\hline \multirow{3}{*}{ Rosuvastatin } & 3 & 0.32 & 0.28 & 87.50 & 4.14 \\
& 3 & 8.00 & 7.30 & 91.25 & 4.28 \\
& 3 & 89.0 & 85.77 & 96.37 & 2.95 \\
Ezetimibe & 3 & 267.0 & 256.84 & 96.19 & 2.15 \\
& 3 & 0.08 & 0.07 & 87.50 & 3.73 \\
& 3 & 2.00 & 1.96 & 98.00 & 2.34 \\
& 3 & 22.0 & 20.89 & 94.95 & 3.01 \\
& 3 & 67.0 & 64.53 & 96.31 & 2.16 \\
\hline
\end{tabular}

To check the precision of the proposed method, same four concentrations of samples as used for extraction recovery were analyzed. The intra-day precision was determined by calculating the relative standard deviation of three replicate analyses of samples on the same day. The inter-day precision was determined by calculating the relative standard deviation of the results from the same samples analyzed on three consecutive days. The results of the precision study are given in Table 2.

Table 2. Intra-day and Inter-day precision of the proposed HPLC method

\begin{tabular}{|c|c|c|c|c|c|c|}
\hline \multirow[t]{2}{*}{ Compound } & \multirow[t]{2}{*}{$\mathrm{n}$} & \multirow{2}{*}{$\begin{array}{l}\text { Conc. } \\
(\mu \mathrm{g} / \mathrm{mL})\end{array}$} & \multicolumn{2}{|c|}{ Intra-day precision } & \multicolumn{2}{|c|}{ Inter-day precision } \\
\hline & & & Mean & RSD (\%) & Mean & RSD (\%) \\
\hline \multirow[t]{4}{*}{ Rosuvastatin } & 3 & 0.32 & 0.31 & 2.29 & 0.28 & 2.54 \\
\hline & 3 & 8.00 & 7.58 & 2.58 & 6.97 & 2.99 \\
\hline & 3 & 89.0 & 84.04 & 0.55 & 80.28 & 2.47 \\
\hline & 3 & 267.0 & 252.41 & 0.56 & 249.18 & 0.67 \\
\hline \multirow[t]{4}{*}{ Ezetimibe } & 3 & 0.08 & 0.07 & 2.09 & 0.07 & 3.12 \\
\hline & 3 & 2.00 & 1.72 & 0.58 & 1.71 & 2.85 \\
\hline & 3 & 22.0 & 21.03 & 0.32 & 20.19 & 1.79 \\
\hline & 3 & 67.0 & 64.02 & 0.84 & 62.61 & 1.89 \\
\hline
\end{tabular}

To check the specificity of the method, chromatograms of the blank plasma and that containing both the components were compared. The blank plasma peaks were well separated from the analyte peaks and hence method is specific. Figure 6 shows the blank plasma chromatograph and Figure 3 shows the chromatogram having concentrations equal to LOQ level.

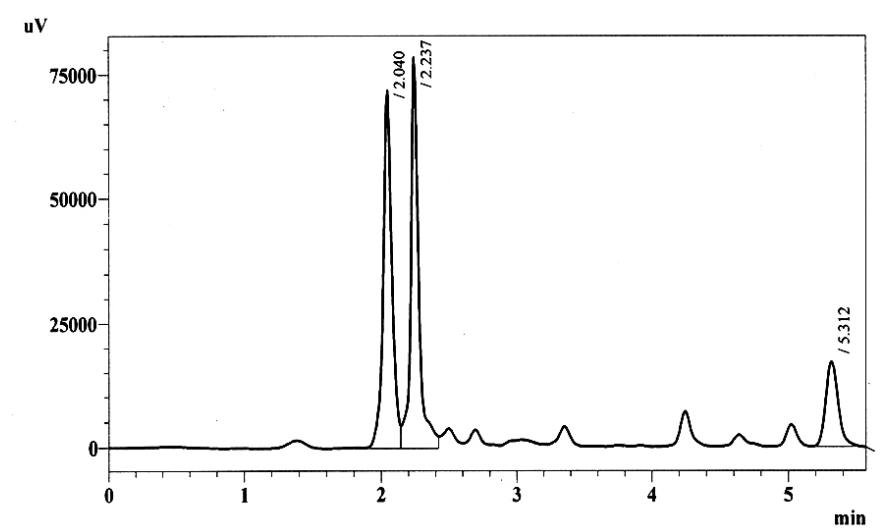

Figure 6: Chromatogram showing blank plasma peaks 
The stability of each component in the presence of other was checked at three different temperature conditions viz. room temperature, $4^{\circ} \mathrm{C}$ and at $-10^{\circ} \mathrm{C}$. These different concentrations were placed at these three different temperature conditions and then their assay was determined after specified time. The results of stability study in spiked human plasma are given in Table 3 and 4, showing the stability of each component for the mentioned period under the specified temperature.

Table 3. Stability study of Rosuvastatin in human plasma

\begin{tabular}{|c|c|c|c|c|c|}
\hline \multirow{3}{*}{$\begin{array}{l}\text { Conc. } \\
(\mu \mathrm{g} / \mathrm{mL})\end{array}$} & \multirow[t]{3}{*}{ Storage Condition } & \multirow{3}{*}{$\begin{array}{l}\text { Recovery } \\
\text { At } \\
\text { Zero time }\end{array}$} & \multicolumn{2}{|c|}{$\%$ of Concentration } & \multirow{3}{*}{$\begin{array}{c}\text { Deviation } \\
(\%)\end{array}$} \\
\hline & & & After & After & \\
\hline & & & 24 hours & 48hours & \\
\hline \multirow[t]{3}{*}{0.32} & Room Temp. & 85.56 & 83.02 & 84.69 & 1.02 \\
\hline & $4^{0} \mathrm{C}$ & 85.56 & 84.21 & 83.75 & 2.12 \\
\hline & $-10^{\circ} \mathrm{C}$ & 85.56 & 80.84 & 83.51 & 2.40 \\
\hline \multirow[t]{3}{*}{8.0} & Room Temp. & 80.70 & 75.15 & 79.25 & 1.80 \\
\hline & $4^{0} \mathrm{C}$ & 80.70 & 79.28 & 80.03 & 0.83 \\
\hline & $-10^{\circ} \mathrm{C}$ & 80.70 & 78.25 & 77.78 & 3.62 \\
\hline \multirow[t]{3}{*}{89.0} & Room Temp. & 85.30 & 83.30 & 82.19 & 3.65 \\
\hline & $4^{0} \mathrm{C}$ & 85.30 & 84.49 & 84.97 & 0.39 \\
\hline & $-10^{\circ} \mathrm{C}$ & 85.30 & 79.92 & 82.52 & 3.26 \\
\hline \multirow[t]{3}{*}{267.0} & Room Temp. & 80.81 & 79.73 & 77.29 & 4.36 \\
\hline & $4^{0} \mathrm{C}$ & 80.81 & 77.24 & 76.26 & 5.63 \\
\hline & $-10^{\circ} \mathrm{C}$ & 80.81 & 73.83 & 73.68 & 8.82 \\
\hline
\end{tabular}

Table 4. Stability study of Ezetimibe in human plasma

\begin{tabular}{|cllccc|}
\hline \multirow{2}{*}{$\begin{array}{c}\text { Conc. } \\
(\mu \mathrm{g} / \mathrm{mL})\end{array}$} & \multirow{2}{*}{ Storage Condition } & \multicolumn{3}{c}{ Recovery } & \multicolumn{2}{c}{ \% of Concentration } & Deviation \\
& & At & After & After & $(\%)$ \\
& & Zero time & 24 hours & 48 hours & \\
\hline \multirow{2}{*}{0.08} & Room Temp. & 90.70 & 92.59 & 90.38 & 0.35 \\
& $4^{0} \mathrm{C}$ & 90.70 & 95.76 & 89.36 & 1.48 \\
& $-10^{\circ} \mathrm{C}$ & 90.70 & 93.18 & 88.59 & 2.33 \\
2.0 & Room Temp. & 88.60 & 85.90 & 85.59 & 2.85 \\
& $4^{\circ} \mathrm{C}$ & 88.60 & 88.70 & 87.26 & 0.94 \\
& $-10^{\circ} \mathrm{C}$ & 88.60 & 86.82 & 86.02 & 2.91 \\
22.0 & Room Temp. & 95.05 & 92.93 & 93.78 & 1.34 \\
& $4^{\circ} \mathrm{C}$ & 95.05 & 93.34 & 93.36 & 1.79 \\
& $-10^{\circ} \mathrm{C}$ & 95.05 & 96.69 & 93.01 & 1.08 \\
67.0 & Room Temp. & 94.00 & 92.48 & 93.45 & 1.65 \\
& $4^{\circ} \mathrm{C}$ & 94.00 & 92.74 & 92.00 & 2.13 \\
& $-10^{\circ} \mathrm{C}$ & 94.00 & 93.01 & 92.02 & 2.10 \\
& & & & & \\
\hline
\end{tabular}

\section{CONCLUSION}

A validated HPLC analytical method was developed for simultaneous determination of rosuvastatin and ezetimibe in spiked human plasma. The validated method is accurate, precise, specific and reproducible for the determination of these drugs in human plasma and may possibly be used for pharmacokinetic studies. Therefore it is concluded that the developed method can be used for any in-vivo studies of these drugs in human beings.

\section{REFERENCES}

1. H. Lennernas, G. Fager. Clin Pharmacokinet., 32, 403(1997)

2. S. E. Nissen, S. J. Nicholls, I. Sipahi, P. Libby, J. S. Raichlen, C. M. Ballantyne, J. Davignon, R. Erbel, J. C. Fruchart, J. C. Tardif, P. Schoenhagen, T. Crowe, V. Cain, K. Wolski, M. Goormastic, E. M. Tuzcu. JAMA. 295(13), 1556(2006)

3. A. G. Olsson, F. McTaggart, A. Raza. Cardiovasc Drug Rev. 20, 303(2002)
4. A. D. McCormick, D. McKillop, C. J. Butters, G. S. Miles, T. Baba, A. Touchi, Y. Yamaguchi. J Clin Pharmacol. 40(9), 1055(2000)

5. A. G. Olsson, J. Pears, J. McKellar, J. Mizan, A. Raza. Am. J Cardiol. 88, 504(2001)

6. R. Paoletti, M. Fahmy, G. Mahla, J. Mizan, H. Southworth. J Cardiovascular Risk. 8, 383(2001)

7. M. Davidson, P. Ma, E. A. Stein, A. M. Gotto Jr, A. Raza, R. Chitra, H. Hutchinson. Am J Cardiol. 89, 268(2002)

8. I. Suslu, M. Celebier, S. Altınoz. Chromatographia. 66, S65(2007)

9. B. Uyar, M. Celebier, S. Altinoz. Pharmazie. 62(6), 411(2007)

10. A. Gupta, P. Mishra, K. Shah. E- Journal of Chemistry. 6(1), 89(2009)

11. C. B. Pandya, K. P. Channabasavaraj, J. D. Chudasama, T. T. Mani. International J Pharm. Sciences Review and Research. 5(10), 82(2010)

12. S. Vittal, N. R. Shitut, T. R. Kumar, M. C. Vinu, R. Mullangi, N. R. Srinivas. Biomed Chromatogr. 20(11), 1252(2006)

13. T. R. Kumar, N. R. Shitut, P. K. Kumar, M. C. Vinu, V. V. Kumar, R. Mullangi, N. R. Srinivas. Biomed Chromatogr. 20(9), 881(2006)

14. T. N. Mehta, A. K. Patel, G. M. Kulkarni, G. Suubbaiah. J AOAC 
International. 88(4), 1142(2005)

15. E. Leitersdorf. Int J Clin Pract. 56(2), 116(2002)

16. M. Van Heek, C. Farley, D. S. Compton, L. Hoos, H. R. Davis. Br J Phamacol. 134, 409(2001)

17. G. Watts. Clin. Sci. 103, 595(2002)

18. R. H. Knopp, H. Gitter, T. Truitt, H. Bays, C. V. Manion, L. J. Lipka, A. P. LeBeaut, R. Suresh, B. Yang, E. P. Veltri. Eur. Heart. 24, 729(2003)

19. G. Salen, K. Von Bergmann, D. Lutjohann, P. Kwiterovich, K. Kane, S. B. Patel, T. Musliner, P. Stein, B. Musser. Circulation. 109, 966(2004)

20. R. P. Dixit, C. R. Barhate, M. S. Nagarsenker. Chromatographia. 67, 101(2008)

21. S.S. Qutab, S.N. Razzaq, I.U. Khan, M. Ashfaq, Z.A. Shuja. J Food Drug Anal., 15(2), 139(2007)

22. M. Ashfaq, I.U. Khan, S.S. Qutab, S.N. Razzaq. J Chil Chem Soc., 52(3), 1220(2007)

23. N. Özaltın, E. Uçaktürk. Chromatographia., 66, 87(2007)

24. B. G. Chaudhari, N. M. Patel, P. B. Shah. J AOAC International. 90(5), 1242(2007)

25. B. G. Chaudhari, N. M. Patel, P. B. Shah, L. J. Patel, V. P. Patel. J AOAC International. 90(6), 1539(2007)

26. P. R. Oliveira, T. Barth, V. Todeschini, S. L. Dalmora. J AOAC international. 90(6), 1566(2007)

27. S. J. S. Basha, S. A. Naveed, N. K. Tiwari, D. Shashikumar, S. Muzeeb, T. R. Kumar, N. V. Kumar, N. P. Rao, N. Srinivas, R. Mullangi, N. R. Srinivas. J Chromatography B., 853, 88(2007)

28. S. Singh, B. Singh, R. Bahuguna, L. Wadhwa, R. Saxena. J Pharm Biomed Anal. 41(3), 1037(2006)

29. R. Sistla, V. S. Tata, Y. V. Kashyap, D. Chandrasekar, P. V. Diwan. J Pharm Biomed Anal. 39(3-4), 517(2005)
30. A. K. Gajjar, V. D. Shah. International Journal of Pharmacy and Pharmaceutical Sciences. 2, 131(2010)

31. A. K. Gajjar, V. D. Shah. International Journal of Pharm Tech Research. 2, 404(2010)

32. M. C. Sharma, S. Sharma, D. V. Kohli, A. D. Sharma. Archives of Applied Science Research. 2, 1(2010)

33. S. Sharma, M. C. Sharma, D. V. Kohli, S. C. Chaturvedi. Der Pharma Chemica. 2, 371(2010)

34. C. B. Pandya, K. P. Channabasavaraj, H. S. Shridhara. International Journal of ChemTech Research. 2, 2140(2010)

35. S. J. Varghese, T. K. Ravi. J AOAC International. 93(4), 1222(2010)

36. S.S. Qutab, S.N. Razzaq, M. Ashfaq, Z.A. Shuja, I.U. Khan Acta Chromatographica, 19, 119(2007)

37. I.U. Khan, S. Sharif., M. Ashfaq, M.N. Asghar., J AOAC International, 91(4), 744(2008)

38. M. Ashfaq, I.U. Khan, M.N. Asghar. J Chil. Chem. Soc., 53(3), 1617(2008)

39. S.S. Qutab, S.N. Razzaq, M. Ashfaq, I.U. Khan, A.M. Mumtaz., J. Chil. Chem. Soc., 54(3), 234(2009)

40. I.U. Khan, S.M.S, Jillani, M. Ashfaq., Lat. Am. J. Pharm., 29, 1383(2010)

41. I.U. Khan, T. Kausar, M. Ashfaq, S. Sharif., 2010. J. Chil. Chem. Soc., 55(4), 461(2010)

42. S. Sharif, I.U. Khan, M. Ashfaq, M.S. Iqbal, S. Ahmad,. J. Anal. Chem., 65, 1029(2010)

43. S.N. Razzaq, I. Mariam, I.U. Khan, M. Ashfaq., J Liq. Chrom. Rel. Technol., 35, 651(2012)

44. S.N. Razzaq, M. Ashfaq, I.U. Khan, I. Mariam. Quim Nova. 35, 1216 (2012).

45. I.U. Khan, M. Ashfaq, S.N. Razzaq, I. Mariam., J. Liq. Chrom. Rel. Technol. 36, 1437 (2013).

46. S.N. Razzaq, M. Ashfaq, I.U. Khan, I. Mariam. Anal. Methods., DOI: 4, $2121(2012)$ 